\title{
Occurrence and distribution of lace bug, whitefly, and shoot fly pest species on cassava (Manihot esculenta) crops according to region in Paraná State, Brazil
}

\section{Ocorrência e distribuição de percevejo-de-renda, mosca-branca e mosca-do-broto na cultura da mandioca (Manihot esculenta) em regiões do Estado do Paraná, Brasil}

Humberto Godoy Androcioli1*; Adriano Thibes Hoshino2; Laura Jane Gisloti3; Ana Beatriz Kawashima4; Luciano Mendes Oliveira4; Mauricio Ursi Ventura5; Bruna Aparecida Guide ${ }^{6}$; Fernando Teruhiko Hata7; Ayres de Oliveira Menezes Junior ${ }^{8}$

\section{Highlights}

Cassava crop was sampled throughout Paraná territory for pest characterization.

Geographic distributions of important cassava pests were characterized.

Two lace bug, two whitefly, and one shoot fly species were often found.

All the insect species were found at least in one Paraná State region.

These damaging species occur where cassava crops have high socioeconomic importance.

\section{Abstract}

The cassava (Manihot esculenta Crantz) crop is relevant for human livelihoods, particularly in poorer regions. It is consumed fresh or as industrialized flour, and the roots and aerial parts are also used to feed

1 PhD, Researcher, Department of Entomology, Instituto de Desenvolvimento Rural do Paraná, IAPAR-EMATER, Londrina, PR, Brazil. E-mail: handrocioli@idr.pr.gov.br

$2 \mathrm{PhD}$, Professor, Undergraduate Course in Agronomy, Universidade Estadual de Londrina, UEL, Londrina, PR, Brazil. E-mail: adriano.hoshino@uel.br

$3 \mathrm{PhD}$, Professor, Post-Graduate Course in Entomology and Biodiversity Conservation, Universidade Federal da Grande Dourados, UFGD, Dourados, MS, Brazil. E-mail: lauragisloti@gmail.com

4 PhD Candidate, Post-Graduate Course in Agronomy, UEL, Londrina, PR, Brazil. E-mail: biakawashima@gmail.com; Imdo2018@gmail.com

5 PhD, Professor, Undergraduate and Post-Graduate Courses in Agronomy, UEL, Londrina, PR, Brazil. E-mail: mventura@uel.br

6 PhD, Professor, Undergraduate Course in Agronomy, Faculdade Pitágoras Unopar, Londrina, PR, Brazil. E-mail: bruhguide@gmail.com

$7 \mathrm{PhD}$, Professor, Undergraduate Course in Agronomy, Universidade Estadual de Maringá, UEM, Maringá, PR, Brazil. E-mail: hata@uel.br

8 PhD, Professor, Undergraduate and Post-Graduate Courses in Agronomy, UEL, Londrina, PR, Brazil. E-mail: ayres@ uel.br

* Author for correspondence

Received: May 31, 2021 - Approved: Oct. 28, 2021 
livestock. Pests may limit cassava production, which may endanger food security due to the socioeconomic importance of the crop. Reports of the occurrence of three insect guilds, lace bugs, shoot flies, and whiteflies have been recorded in Paraná State, Brazil, but the distinct species and their distribution are yet to be determined. This lack of information limits the development of strategies to mitigate pest damage. Surveys were conducted in 39 counties (four farms per county) distributed throughout the state that encompass the various socioeconomic regions. The collected material was properly packed and sent to the laboratory for identification, and the following species were identified: lace bugs Vatiga illudens Drake, 1922 and Vatiga manihotae Drake, 1922 (both Hemiptera: Tingidae); whiteflies Bemisia tuberculata (Bondar, 1923) and Aleurothrixus aepim (Goeldi, 1886) (both Hemiptera: Aleyrodidae), and the cassava shoot fly Neosilba perezi Romero \& Ruppel, 1973 (Diptera: Lonchaeidae) in Paraná State. Lace bugs were not found in the samples in the eastern and southern portions of the state. $V$. illudens was more widespread than $V$. manihotae. The whitefly A. aepim was not observed in three counties (eastern, southern, and central regions), whereas $B$. tuberculata and the cassava shoot fly were found in all regions sampled in Paraná State. Suggestions for future investigations of pest management are proposed.

Key words: Aleurothrixus aepim. Bemisia tuberculata. Cassava pests. Neosilba perezi. Vatiga spp.

\section{Resumo}

A cultura da mandioca é relevante para o sustento humano principalmente para regiões pobres, seu consumo ocorre na forma in natura ou como farinha industrializada. Raízes e parte aérea são também utilizadas para criação animal. As pragas podem limitar a produção de mandioca, o que pode ameaçar a segurança alimentar pela importância sócio-econômica da cultura. Registros da ocorrência de três guildas de insetos: percevejos-de-renda, moscas-do-broto e moscas-brancas são recorrentes no Estado do Paraná, mas quais espécies e a sua distribuição ainda não foram amplamente determinadas. A falta de informação limita o desenvolvimento de estratégias para mitigar eventuais danos ocasionados pelas pragas. Assim, levantamentos foram feitos em 39 cidades (quatro campos por cidade) distribuídas por todo o estado englobando as regiões sócio-econômicas. O material coletado foi devidamente acondicionado e enviado ao laboratório para identificação, determinando-se as seguintes espécies: os percevejos-de-renda Vatiga illudens Drake, 1922 e Vatiga manihotae Drake, 1922 (ambos Hemiptera: Tingidae), as moscas-brancas Bemisia tuberculata (Bondar, 1923) e Aleurothrixus aepim (Goeldi, 1886) (ambos Hemiptera: Aleyrodidae) e a mosca-do-broto da mandioca Neosilba perezi Romero \& Ruppel, 1973 (Diptera: Lonchaeidae) no Paraná. Os percevejos-de-renda não foram encontrados nas amostras das regiões leste e sul do Estado. A maior distribuição espacial ocorre para- $V$. illudens em relação a $V$. manihotae. A mosca-branca $A$. aepim não foi encontrada em três municípios do estado (leste, sul e região central), enquanto $B$. tuberculata e a moscado-broto foram encontradas em todas as regiões amostradas no Paraná. Sugestões para futuras pesquisas são apresentadas.

Palavras-chave: Aleurothrixus aepim. Bemisia tuberculate. Pragas da mandioca. Neosilba perezi. Vatiga spp. 


\section{Introduction}

Cassava (Manihot esculenta Crantz) is a semi-perennial heliophilic shrub of the Euphorbiaceae family (Lorenzi, Otsubo, Monteiro, \& Valle, 2002) that originated in South America and is grown in several regions worldwide between $30^{\circ} \mathrm{N}$ and $30^{\circ} \mathrm{S}$ (Otsubo \& Lorenzi, 2004). Cassava crops are one of the principal carbohydrate sources and constitute the food base for many populations, particularly in Africa and Brazil (Latif \& Müller, 2015). Due to its adaptability under low fertility soils, drought, and heat, cassava can be cultivated in agricultural environments where other crops do not thrive (Burns, Gleadow, Cliff, Zacarias, \& Cavagnaro, 2010; Rosenthal et al., 2012). Hence, cassava crops occupy an increasing portion of croplands globally and may expand further under climate change scenarios. Biotic and abiotic factors may limit cassava yields, and insect pests can damage leaves and stems (El-Sharkawy, 2004; Bellotti, Campo, \& Hyman, 2012).

Paraná state is the second largest national cassava producer, and harvests approximately 3 million tons of roots (Instituto Brasileiro de Geografia Estatística [IBGE], 2018). Three insect pest guilds have been reported that concern farmers and agricultural extension officers in the state: lace wings, whiteflies, and cassava shoot flies. In addition, farmers alter their propagative material (cutting stems), which can increase pest spread throughout different regions.

In Brazil, five lace bug species (Hemiptera: Tingidae) have been reported in cassava plants: Vatiga varianta Drake, $1930, V$. cassiae Drake \& Hambleton, 1934, V. illudens Drake, 1922, V. manihotae Drake, 1922, and
Gargaphia opima Drake, 1931 (Bellotti, Smith, \& Lapointe, 1999; Bellotti, 2002; Santos, Coelho, \& Wengrat, 2019). The whiteflies (Hemiptera: Aleyrodidae) Aleurotrachelus socialis Bondar, 1923, Trialeurodes variabilis Quaintance, 1900, Bemisia tuberculata Bondar, 1923, and Aleurothrixus aepim (Goeldi, 1886) have also been frequently reported (M. R. V. Oliveira, Moretzshon, Queiroz, Lago, \& Lima, 2001; Bellotti, 2002; Rheinheimer et al., 2009; Pietrowski, Rheinheimer, Miranda, Wengrat, \& Barilli, 2014). The shoot fly Neosilba perezi Romero \& Ruppel, 1973 (Diptera: Lonchaeidae) has also been commonly observed in cassava plantations, with the majority in Neotropical regions (Bellotti et al., 1999). Data on the biology of cassava pests are relatively scarce. In general, cassava pests prefer the same conditions as the affected plant. $N$. perezi shows improved development under warming temperatures (Waddill, 1977) and has a life cycle of approximately 40 days (Gisloti \& Prado, 2013). V. illudens populations are affected by temperature, but not by precipitation and relative humidity (Bellon et al., 2017). The biological life cycle of $V$. manihotae occurs over approximately 22 days $(25+2$ ) (Miranda, Rheinheimer, Bellon, Gazola, \& Pietrowski, 2009). At $26+4$ B. tuberculata survives for approximately 26 days (Andrade, Roel, Penteado-Dias, \& Costa, 2012) and, for A. aepim, at similar temperatures, but reared on different cassava cultivars, the lifecycle varies from 26.8 to 30.5 days (Lima, Ringenberg, Fancelli, \& Ledo, 2018).

These pests may damage cassava crop yields, thereby compromising food security due to the importance of the crop for the livelihood and income of farmers with small cultivations. The prevalent species and 
their distribution in Paraná State territory are currently unknown; therefore, we sampled four cassava fields in each of the 39 counties throughout Paraná State, thereby encompassing all socioeconomic regions, to collect and identify lace bugs, whiteflies, and shoot flies. Specimens were identified and the occurrence of the species was recorded and geographically characterized.

\section{Material and Methods}

The occurrence of lace bugs, whiteflies, and shoot flies was studied in Paraná State, Brazil, from 2015 to 2018. Surveys were conducted in 39 counties distributed throughout the state to represent the various socioeconomic regions. Collections were obtained from four cassava fields on distinct farms per county. Plants were randomly sampled (30 per farm) in the field, and specimens were sent to the Laboratory of Entomology [Instituto de Desenvolvimento Rural do Paraná - IAPAR-EMATER (IDR-Paraná)] in Londrina County for identification.

Collection and identification of lace bug species

Lace bugs were collected manually from the abaxial surface of cassava leaves. The specimens were placed in pots containing an ethanol solution (70 \%). Taxonomic identification was achieved using stereoscopic microscopy to observe morphological head traits, number of thorns and tubercles, and the color of the tissue and reticular aspects according to the identification key proposed by Froeschener (1993).
Collection and identification of whitefly species

Plants were sampled to examine for whitefly nymphs in cassava leaves. Species identification was achieved using morphological characters of $4^{\text {th }}$ instar nymphs. Nymphs were removed from the leaves using a pin and placed on slides for microscopy (Motic BA 300). Morphological descriptions from Bondar (1923) and Quaintance and Baker (1914) were used to identify the species.

Collection and identification of the shoot fly species

The observation of a brown exudate in holes of plant parts was an indication of pest attack, and these were collected for examination. Apical stems were sectioned (30 $\mathrm{cm}$ length), placed in Styrofoam boxes, and sent to the laboratory. Two injured stems were placed in each plastic bottle $(2 \mathrm{~L})$ filled with fine vermiculite to a level $10 \mathrm{~cm}$ from the bottom. The bottles were then closed using a voile cloth (mesh lower than $0.5 \mathrm{~mm})(40 \times 20 \mathrm{~cm})$ fixed with rubber bands and placed on plastic trays containing water to retain the moisture. Trays were then transferred to environmental chambers ( $\mathrm{T} 25 \pm 3{ }^{\circ} \mathrm{C}, 70 \pm 10 \% \mathrm{RH}$, photoperiod 14:10 L:D). Emerged adults were collected, placed in a $70 \%$ ethanol solution, and sent to the Entomology and Biodiversity Conservation Department at Universidade Federal da Grande Dourados, Dourados, MS, Brazil, where they were identified using the identification keys proposed by Zucchi (2000). 
Creation of the geographic distribution maps

The ArcGis 10.3 software was used to compose the geographic distribution maps of the principal pests of cassava crop in Paraná State.

\section{Results and Discussion}

The surveys conducted confirmed that the cassava fields hosted three pest insect guilds in Paraná State: lace bugs $V$. illudens and $V$. manihotae (Figure 1), whiteflies $B$. tuberculata (Figure 2) and $A$. aepim (Figure 3), and the shoot fly $N$. perezi (Figure 4).

$V$. illudens and $V$. manihotae were found in the northwest region (Campo Mourão and Paranavaí), western region (Palotina, Marechal Cândido Rondon, Cascavel, and Realeza), and in Londrina County in the north (Figure 5). V. illudens was the only lace bug species found in the mid-south and coastal regions. The absence of these two species in the southern portion of the state suggests that they may be affected by lower temperatures. In previous studies, V. illudens was were predominant in Brazil territory (Bellotti et al., 1999); however, Pietrowski et al. (2010) reported V. manihotae as the principal species in western Paraná.

In general, the lace bugs $V$. illudens and $V$. manihotae did not damage cassava fields; however, an apparent population increase, favored by specific climatic and soil fertility conditions, mainly in the Paraná and Mato Grosso States, has suggested that these insects are potential cassava pests (Fialho et al., 2001; Bellotti, 2002; Farias \& Alves 2004; Bellon, Wengrat, Kassab, Pietrowski, \& Louriero, 2012). Nymphs and adult lace bugs injure plants by feeding on cell protoplasts, leading to chlorotic white spots on the adaxial leaf surface, which evolve to a brown-red, and may defoliate the plant completely in high abundance (Bellotti, 2002). Field populations vary according to the period of the year and specific cultivar (Martinazzo et al., 2007). 


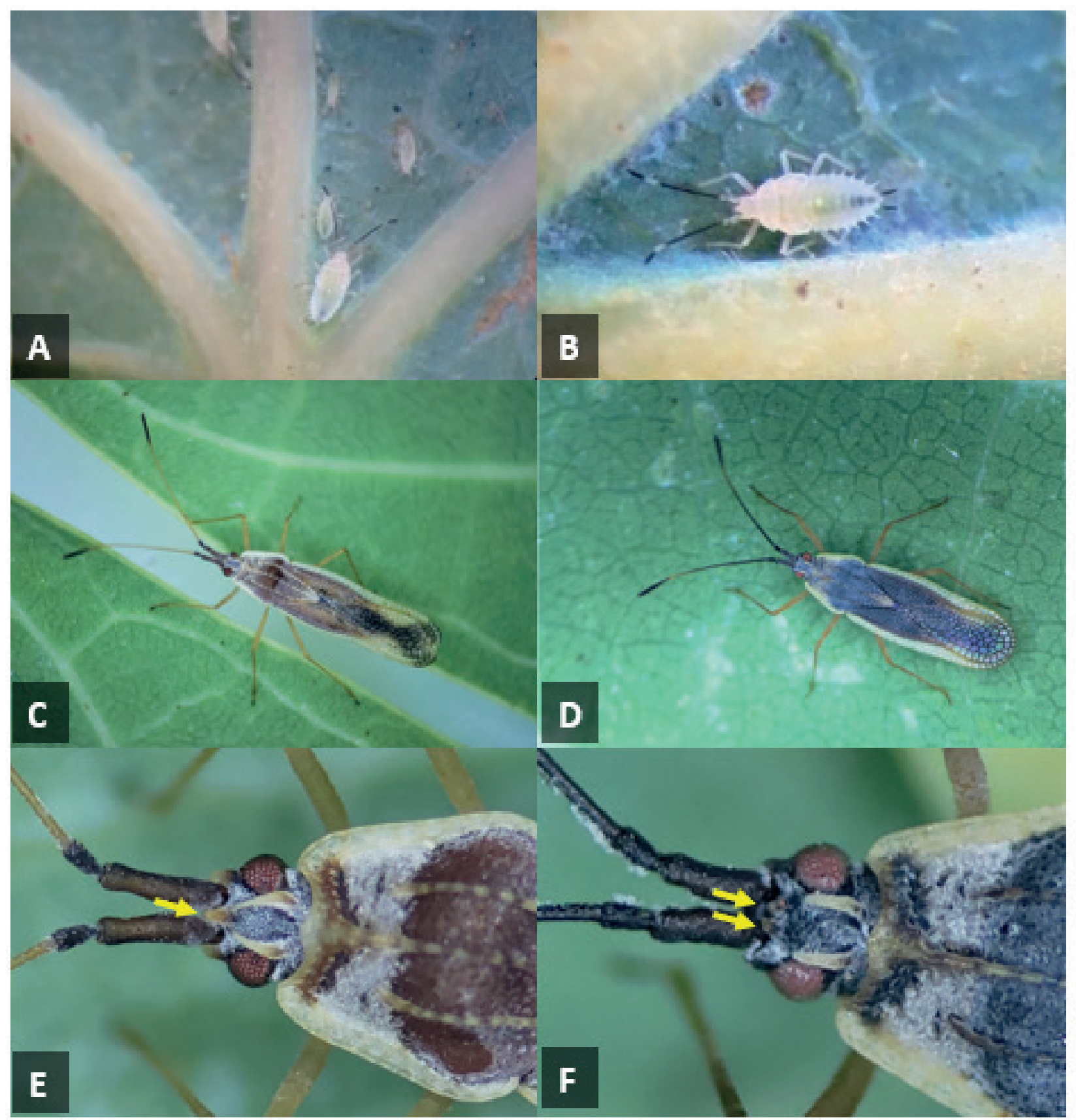

Figure 1. Nymphs of Vatiga sp. in the abaxial surface of the cassava leaf (A); detail of the $4^{\text {th }}$ instar nymph (B); adult of Vatiga illudens Drake, 1922 (C); adult of de Vatiga manihotae Drake, 1922 (D); detail of thorns in the anterior portion of the head (yellow arrows), a single one for $V$. illudens (E) and two for V. manihotae (F). 


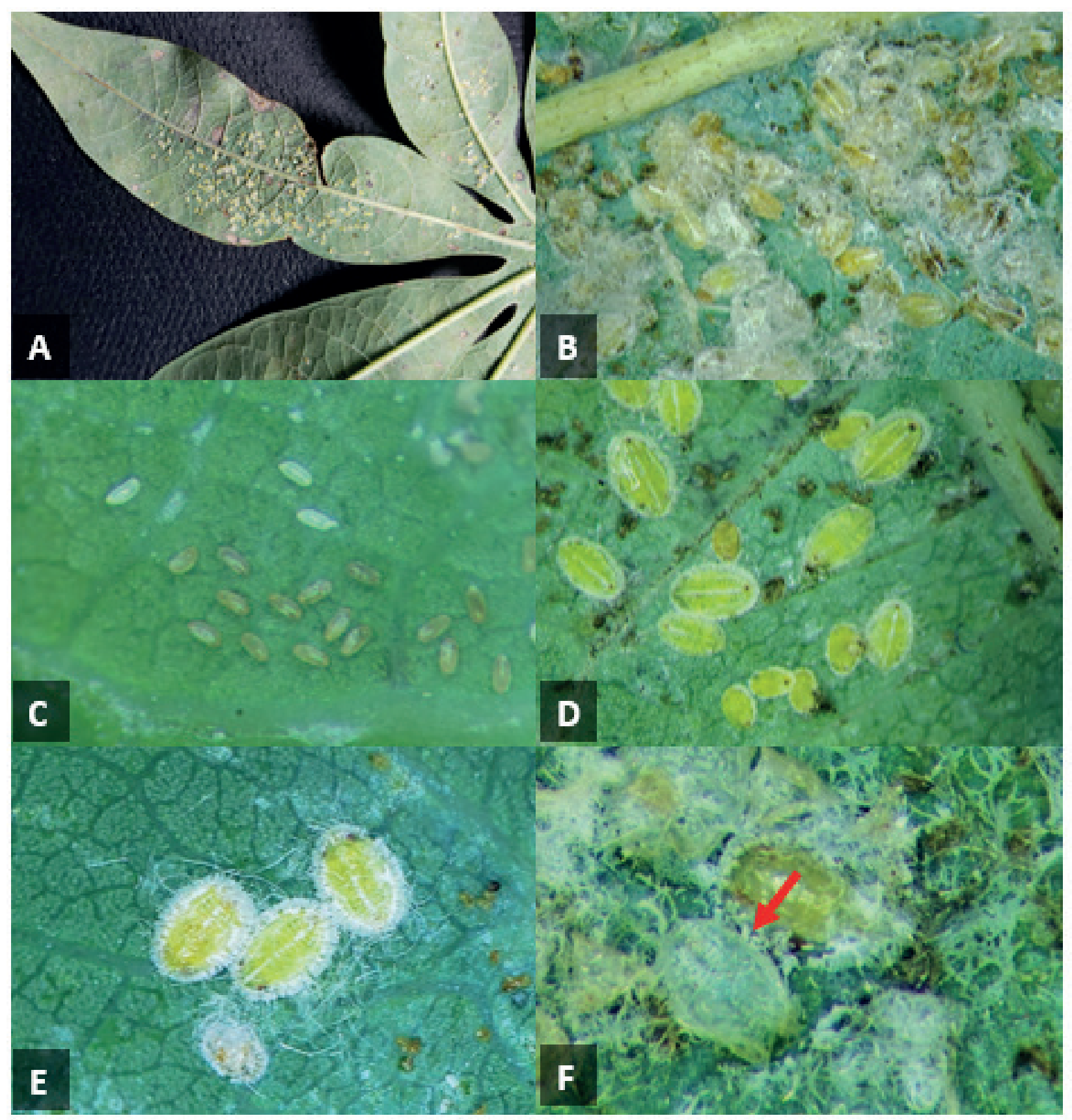

Figure 2. Aleurothrixus aepim (Goeldi, 1886): abaxial surface of cassava leaf hosting nymphs (A and $B$ ); eggs $(C)$, detail of the nymphs of $2^{\text {nd }}$ and $3^{\text {rd }}$ instars (D); nymphs of $4^{\text {th }}$ instar $(E)$; exuvia of $4^{\text {th }}$ instar indicated by red arrow (F). 


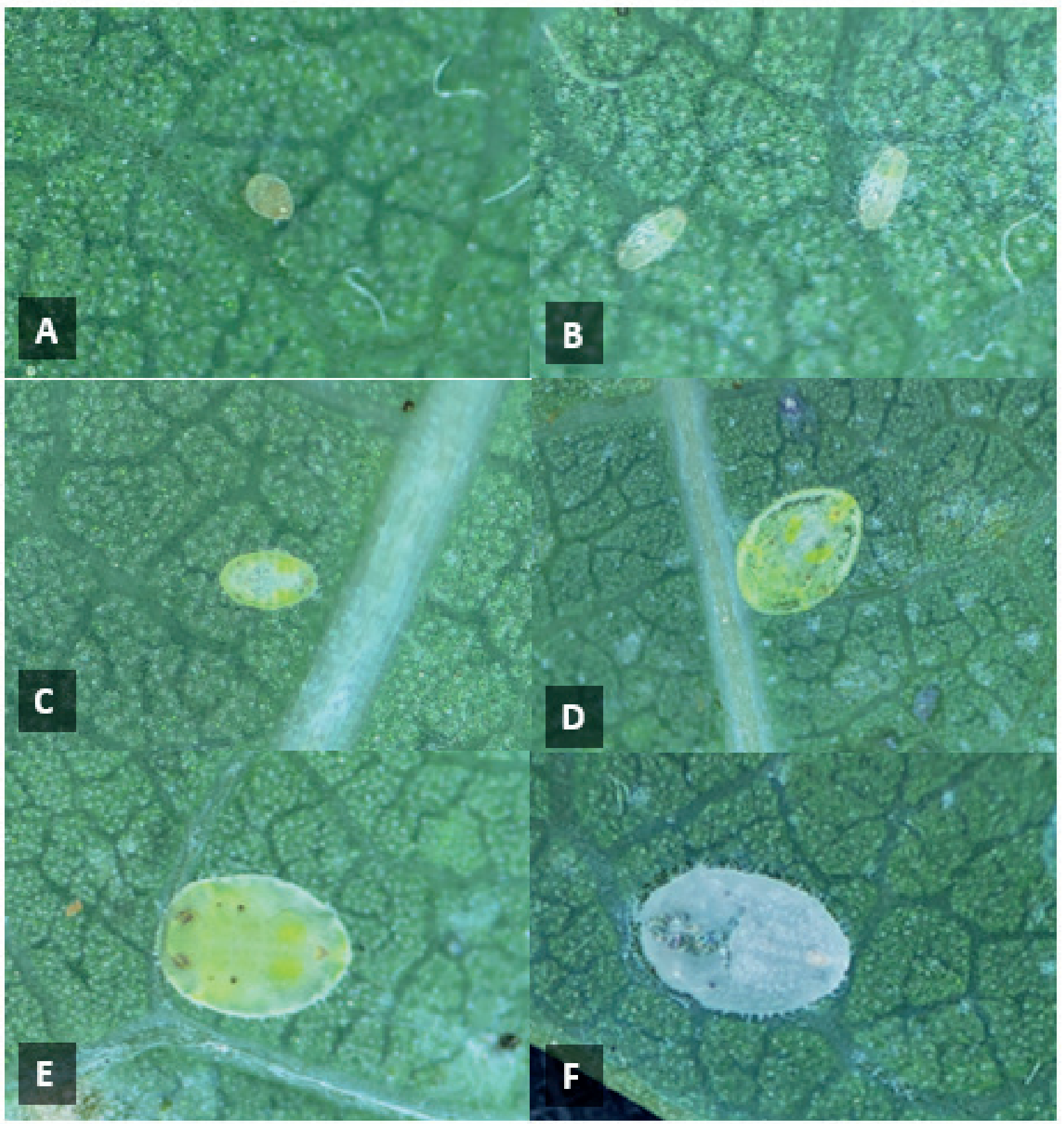

Figure 3. Bemisia tuberculata (Bondar, 1923): egg (A); nymphs of $1^{\text {st }}$ instar $(B)$; nymphs of $2^{\text {nd }}(C), 3^{\text {rd }}$ $(D)$ and $4^{\text {th }}(E)$ instars; exuvia of $4^{\text {th }}$ instar $(F)$. 


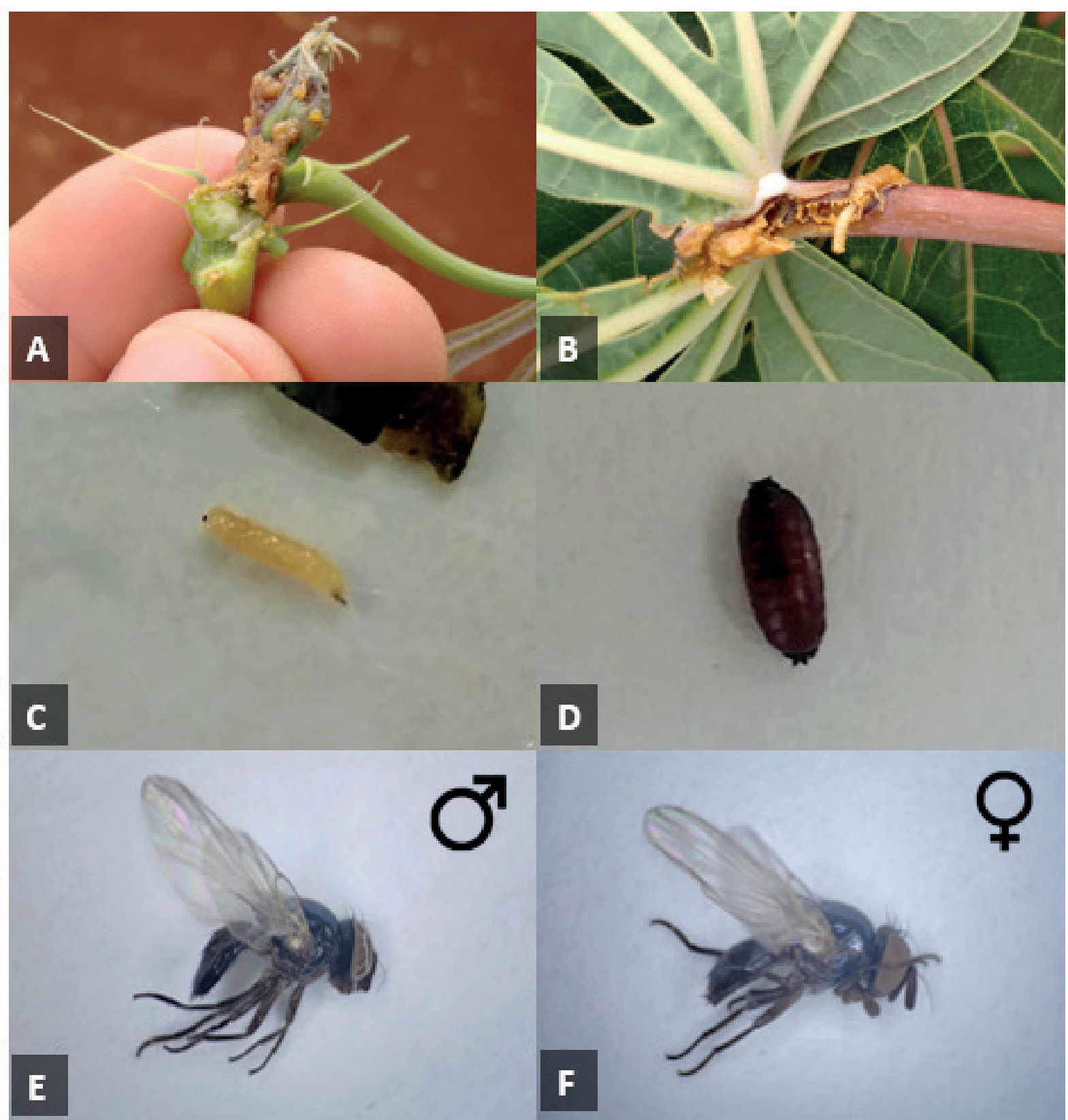

Figure 4. Neosilba perezi Romero \& Ruppel, 1973: shoot (A) and leaf petiole (B) injuries in cassava plants; details of the larva (C) and pupa (D); lateral view of adult male (E) and female (F).

Reduction of cassava root and leaf yields was reported in studies over four years on field plots with or without chemical controls, and damage was characterized as reaching $55 \%$ (Fialho, Vieira, Paula-Moraes, Silva, \& Junqueira, 2009). Another study found that
$39 \%$ of root yields were decreased by pest damage (Bellotti et al., 1999). Recent studies have identified a negative correlation between the population of adult insects and root yield (Bellon et al., 2017). 


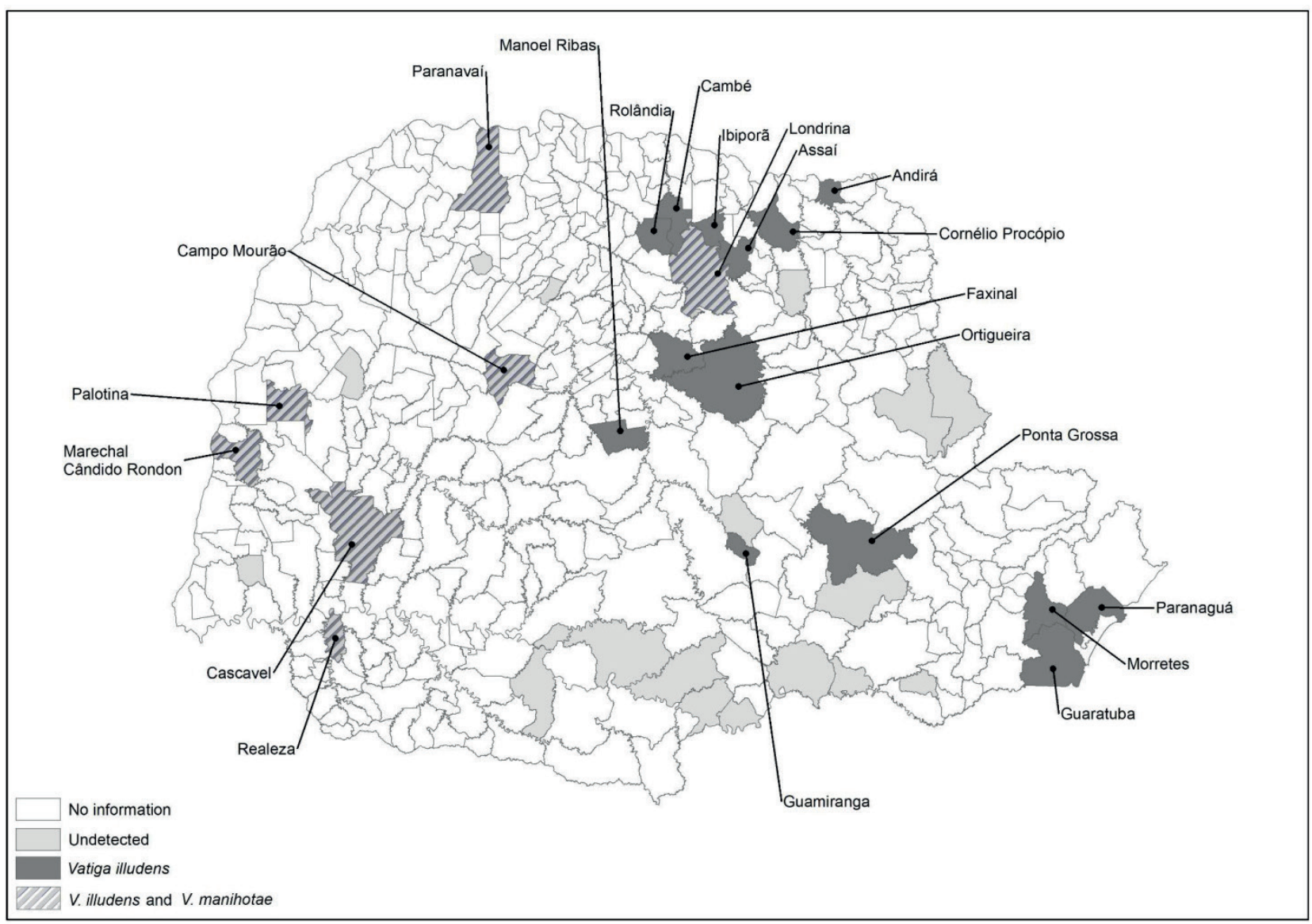

Figure 5. Occurrence of Vatiga illudens and Vatiga manihotae in Paraná State, Brazil.

Whiteflies were observed throughout the Paraná state (Figure 6), and B. tuberculata was found in all the sample sites and was the only species in Sengés, Ivaí, and São Mateus do Sul counties. In the western region, $A$. aepim and B. tuberculata were observed, which confirms previous reports indicating the introduction of $A$. aepim (Pietrowski et al., 2014). According to those authors, this species was not previously detected in the other parts of the state and its presence throughout the state (Figure 2) suggests its rapid spread. This B. tuberculata distribution indicates a possible concern for cassava production, considering previous reports of productivity reduction caused by outbreaks of this species in Southern Brazil (M. R. V. Oliveira et al., 2001; Bellotti, 2002; Bellotti et al., 2012).

Eleven species belonging to nine genera of whitefly were recorded in cassava plants in the Neotropical region (VásquezOrdóñez, Hazzi, Escobar-Prieto, Paz-Jojoa, \& Parsa, 2015). A. socialis, A. aepim, and B. tuberculata have been reported as having high damage potential in Brazil (Pietrowski et al., 2014). A. aepim was observed to occur in dense populations, causing a decrease in yield in the northeastern regions (M. R. V. Oliveira et al., 2001). In the midwest, B. tuberculata and T. variabilis were reported (M. R. V. Oliveira et al., 2001). 
Whiteflies feed on plant sap and directly damage apical leaves. Consequently, leaf curling, chlorosis, withering, necrosis, and leaf fall occur. During feeding, whiteflies also produce honeydew (M. R. V. Oliveira \& Lima, 2006) which is a suitable substrate for sooty mold fungi (Capnodium spp.), which produces a barrier that impairs photosynthesis (Moreira,
Farias, Alves, \& Carvalho, 2006). Indirect damage also occurs by virus transmission, which includes "Cassava frogskin-associated virus" (CsFSaV), which leads to more fibrous and bitter roots. Infested plants also become more aqueous, and crop productivity can decrease up to $79 \%$ (Bellotti, 2002; Schimitt, 2002).

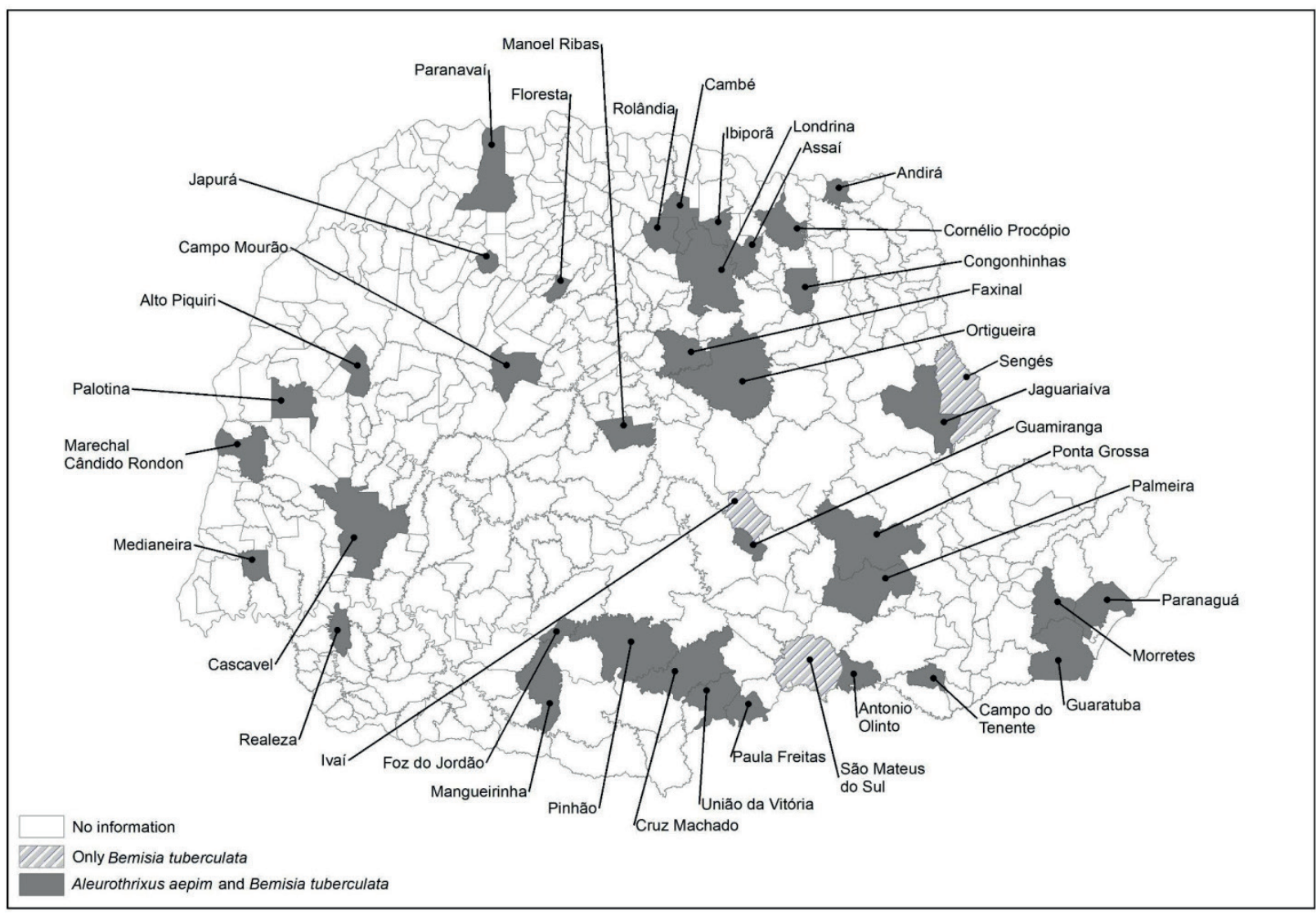

Figure 6. Occurrence of the whitefly species Aleurothrixus aepim and Bemisia tuberculata in Paraná State, Brazil.

In the present study, the cassava shoots fly $N$. perezi occurred throughout Paraná State (Figure 7). Previous studies have characterized the damage caused by shoot flies in the western region of Paraná (Marechal Cândido Rondon County) (Weber et al., 2015). Although information on $\mathrm{N}$. perezi bioecology remains scarce, damage is characterized by larva that feed by penetrating the plant stems, causing exudation of a yellowish secretion, which subsequently becomes brown. This damage can favor the infection process by phytopathogenic microorganisms (Lozano, Bellotti, \& Vargas, 1983; Bellotti, 2002; L. S. 
Souza \& Fialho, 2003; De Lorenzi \& Nora, 2016). Infested shoots can die and result in excessive sprouting of lateral gems due to loss of apical dominance of the plant, resulting in delayed plant development (Lozano et al., 1983; L. S. Souza \& Fialho, 2003; Gisloti \& Prado, 2013).

In general, flies of the Tephritoidea superfamily and Lonchaeidae family, which include Neosilba, are polyphagous and the larvae are associated with organic matter (Gisloti, Uchoa, \& Prado, 2017). Originating from the Neotropical region, N. perezi has been reported in South (Bellotti et al., 1999), Central (Saunders, Coto, \& King, 1998; Bellotti, 2008; De Lorenzi \& Nora, 2016), and North America (Peña \& Waddill, 1982).

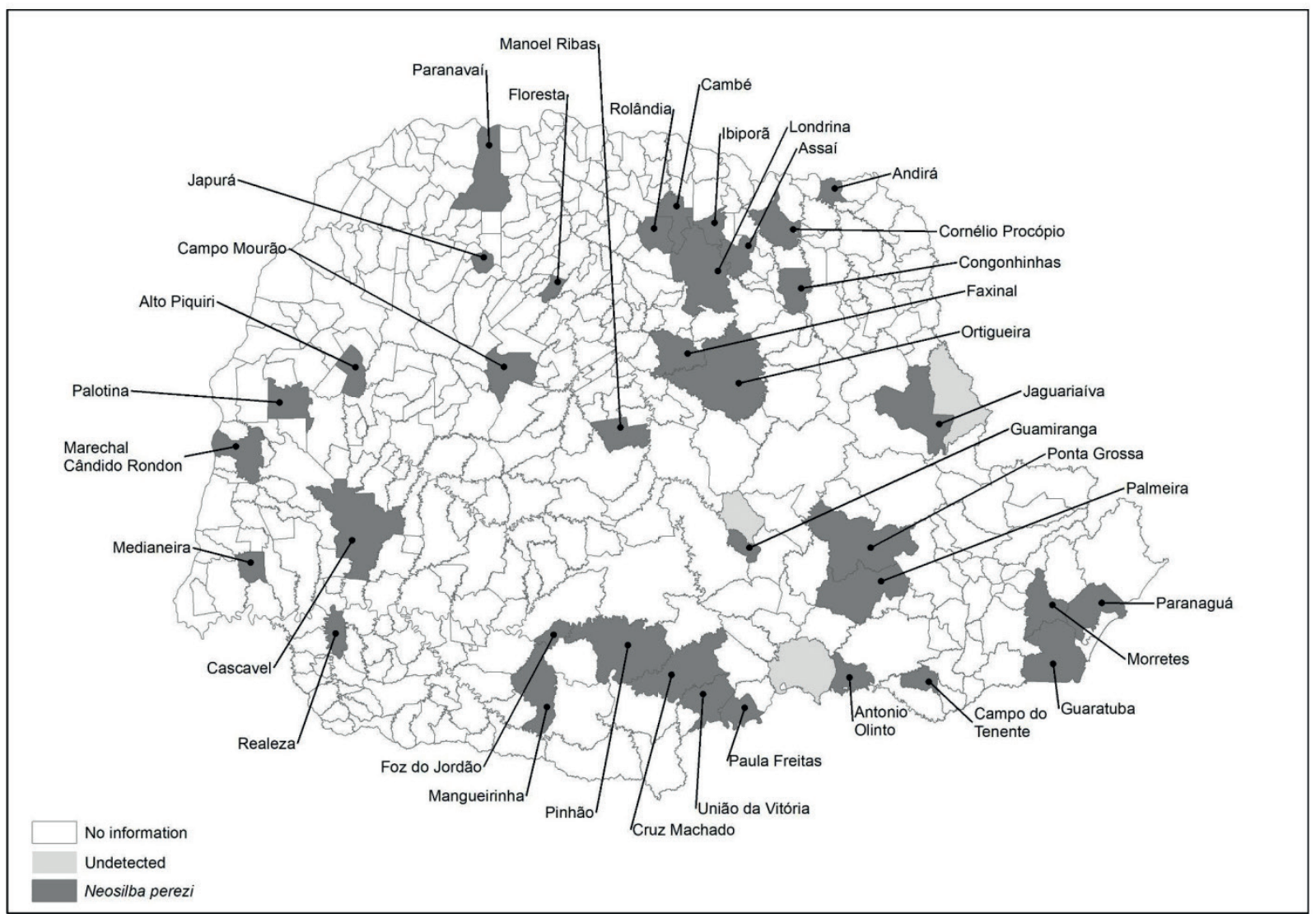

Figure 7. Occurrence of the shoot fly Neosilba perezi in Paraná State, Brazil.

In Brazil, the shoot fly was first reported in 1940 (Graner, 1942; Zikan, 1944), with LonchaeapendulaBezzi, 1919. This species has been documented in all geopolitical regions of the country, including the states of Amazonas (Silva, Magalhães, \& Costa, 1981), Paraíba (S. D. Souza, Matias, \& Lopes, 1982), Minas Gerais (J. C. Souza \& Reis, 1986; Strikis, Marsaro, Adaime,
\& Lima, 2012), Rondônia (F. N. S. Oliveira, 1987), Bahia (Gisloti \& Prado, 2011; Farias, Mattos, \& Ferreira, 2007; A. M. G. Oliveira et al., 2007), Santa Catarina (De Lorenzi \& Nora, 2016), and São Paulo coastal and inland regions (Graner, 1942; Lourenção, Lorenzi, \& Ambrosano, 1996; Gisloti \& Prado, 2011). Results of simulated damage on different cassava cultivars showed 
that root yields may reach $30 \%$ in late cultivars and from 51 to $71 \%$ in cassava stem cuttings (Bellotti, 2002).

The findings reported here have implications for future investigations. Plant resistance is a preferred choice for pest management, particularly for cassava crops, which are utilized in low-income and familiar agriculture (Barilli et al., 2019). Cassava plant breeding programs, including insect pest resistance assessments, could be successful if field experiments occurred in regions where all pest species occur, as this would establish a complete characterization of the responses of the cultivars to all species.

The common use of chemical pest control is impractical for cassava crops, except in regions where larger areas are cultivated, such as Paraná State Northwest (Figure 8). The limitations include low availability of commercial insecticides officially allowed for cassava fields, the lack of suitable equipment and safety clothing in small farms, and the insufficient information available on selectivity to natural enemies, costs, etc. Consequently, chemical control is not economically viable for small cassava plantations (Pinto-Zevallos, Pareja, \& Ambrogi, 2016).

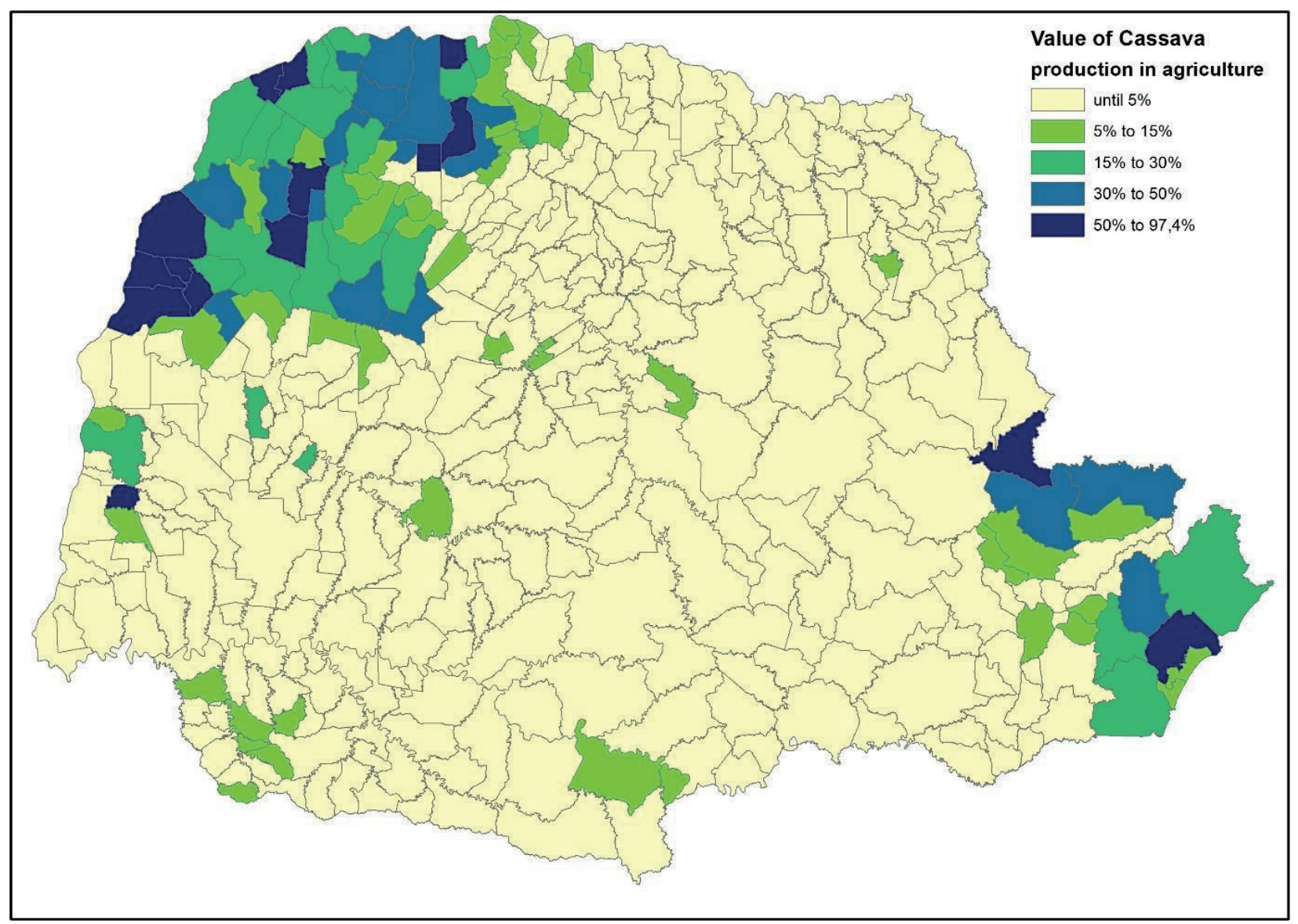

Figure 8. Percentage of cassava production in relation to other agricultural crops according to county in Paraná State, Brazil.

Source: IBGE (2018). 
The biological control of cassava crops remains poorly studied. Knowledge of the sites of these pests may allow further investigations to determine the populations of natural enemies under different cultivation systems.

Another challenge is that all pest species were observed in the Northwest region, which is the principal cassava producer in the state, and since it is one of the main cash crops, it has great economic importance for regional agriculture (Figure 8). With the exception of $V$. manihotae, all other species sampled were recorded in the coastal region, in which cassava also has great economic and social relevance because it is sold as a fresh tuber and carbohydrate source for consumers, and as a supply for small cassava flour factories. These crops could be a unique income source for resource-poor families. In general, cassava pests develop properly in environmental conditions that are suitable for the related plants, particularly under higher temperatures (Waddill, 1977; Gisloti \& Prado, 2013; Bellon et al., 2017; Miranda et al., 2009; Andrade et al., 2012), which generally occur in the Paraná regions in spring and summer.

Cassava is frequently cultivated in marginal lands (Pushpalatha \& Gangadharan, 2020), such as the Paraná regions, where the crophasarelativelygreateconomicimportance. The northwest has sandy soils and crops are found on hillsides through to the coastal region. Cassava crops may succeed even in resource-poor soils and environments. These land traits combined with crop characteristics such as erect architecture, poor canopy cover in the early growing season, a harvest scheme of soil-disturbing tillage, and production continuation despite the soil degradation (Delaquis, Haan, \& Wyckhuys, 2018) foster the objective conditions for high erosion levels. Environmental services such as biodiversity improvement, soil conservation, and pest and disease population reductions can be enhanced by intercropping and agroforestry (Delaquis et al., 2018). Hence, considering the presence of pest species in these regions and the previous reports of damage, it is of particular importance to include the effects of these multifunctional strategies on insect pest population dynamics in multidisciplinary studies. In this regard, cassava plant genotypes may secrete excess floral nectar (Burns et al., 2010) which may contribute to the increase of parasitoid and predator populations, not only for the specific crop, but eventually for entire polyculture production systems. In general, cassava plants are considered to have relatively high defensive strategies against pests and diseases (Pinto-Zevallos et al., 2016; Barilli et al., 2021). Designing an approach using cassava as a "suitable neighboring plant" could also contribute to chemically-mediated associational resistance (Barbosa et al., 2009).

\section{Conclusion}

In summary, the lace bugs $V$. manihotae and $V$. illudens, whiteflies $A$. aepim and $B$. tuberculata, and the shoot fly N. perezioccurred in cassava crops in Parana State. Lace bugs were not found in the southern portions of the state. $V$. illudens was more widespread than $V$. manihotae. Whiteflies were located in almost the entire Parana State, except for A. aepim, which was not found in the eastern, southern, and central regions. The cassava shoot fly was observed in all regions sampled in Paraná State. 


\section{Acknowledgements}

We thank the Instituto de Desenvolvimento Rural do Paraná - IAPAREMATER for financial and logistical support to conduct this work, and the Coordenação de Aperfeiçoamento de Pessoal de Nível Superior (CAPES) for granting a scholarship to the third and fourth authors. Wealso thank the producers for allowing us to inspect their properties. We especially thank Dr. João Henrique Caviglione (in memoriam) for assistance during this study.

\section{References}

Andrade, N. N., Fo., Roel, A. R., Penteado-Dias, A. M., \& Costa, R. (2012). Biology of Bemisia tuberculata Bondar (Aleyrodidae) and parasitism by Encarsia porteri (Mercet, 1928) (Hymenoptera, Aphelinidae) on cassava plants. Brazilian Journal of Biology, 72(4), 903-907. doi: 10.1590/ S1519-69842012000500017

Barbosa, P., Hines, J., Kaplan, I., Martinson, H., Szczepaniec, A., \& Szendrei, Z. (2009). Associational resistance and associational susceptibility: having right or wrong neighbors. Annual Review of Ecology, Evolution, and Systematics, 40(1), 1-20. doi: 10.1146/annurev.ecolsys. 110308.120242

Barilli, D. R., Budzinski, I. G. F., Bronzel, J. L. Jr., da Silva B. V., Boiça Junir, A. L., \& Rossi, G. D. (2021). GC-MS analyses reveal chemical differences in the leaves of Manihot esculenta Crantz genotypes with different anti-herbivore effects. Arthropod-Plant Interactions, 15(3), 387-398. doi: 10.1007/ s11829-02 1-09822-8

Barilli, D. R., Silva Wengrat, A.P. G. da, Guimarães, A. T. B., Pietrowski, V., Ringenberg, R., \& Garcia, M. S. (2019). Resistance of cassava genotypes to Bemisia tuberculata. Arthropod-Plant Interactions, 13(4), 663669. doi: 10.1007/s11829-019-09694-z

Bellon, P. P., Oliveira, H. N. D., Loureiro, E. D. S., Santana, D. R. S., Otsubo, A. A., \& Mota, T. A. (2017) Populational fluctuation of lace bug in cassava. Arquivos do Instituto Biológico, 84(1), 1-6. doi: 10.15 90/18081657000602015

Bellon, P. P., Wengrat, A. P. G. S., Kassab, S. O., Pietrowski, V., \& Loureiro, E. D. (2012). Occurrence of lace bug Vatiga illudens and Vatiga manihotae (Hemiptera: Tingidae) in Mato Grosso do Sul, midwestern Brazil. Anais da Academia Brasileira de Ciências, 84(3), 703-705. doi: 10.1590/S0001-3765 2012000300012

Bellotti, A. C. (2002). Arthropod pests. In R. J. Hillocks, J. M. Thresh,. \& A. C. Bellotti (Eds.), Cassava: biology, production, and utilization (pp. 209-235). New York, NY: CABI Publishing.

Bellotti, A. C. (2008). Cassava pests and their management. In J. L. Capinera (Ed.), Encyclopedia of entomology (pp. 764794). Berlin: Springer.

Bellotti, A. C., Campo, B. V. H., \& Hyman, G. (2012). Cassava production and pest management: present and potential threats in a changing environment. Tropical Plant Biology, 5(1), 39-72. doi: 10.1007/s120 42-011-9091-4

Bellotti, A. C., Smith, L., \& Lapointe, S. L. (1999). Recent advances in cassava pest management. Annual Review of Entomology, 44(1), 343-370. doi: 10.1146/ annurev.ento.44.1.343

Bondar, G. (1923). Aleyrodídeos do Brasil: catálogo descriptivo dos HemipterosHomopteros da familia dos Aleyrodideos, insectos parasitas das plantas, encontrados no Brasil. [Salvador], 
Secretaria da Agricultura, Indústria e Obras Públicas do Estado da Bahia. Secção de Pathologia Vegetal, 1(1), 183. doi: 10.5962/bhl.title.70899

Burns, A., Gleadow, R., Cliff, J., Zacarias, A., \& Cavagnaro, T. (2010). Cassava: the drought, war and famine crop in a changing world. Sustainability, 2(11), 3572-3607. doi: 10.3390/su2113572

De Lorenzi, E. F. P., \& Nora. I. (2016). Danos e manejo da mosca-do-broto da mandioca. Agropecuária Catarinense, 29(3), 38-41.

Delaquis, E., Haan, S. de, \& Wyckhuys, K. A. (2018). On-farm diversity offsets environmental pressures in tropical agro-ecosystems: a synthetic review for cassava-based systems. Agriculture, Ecosystems \& Environment, 251(1), 226235. doi: 10.1016/j.agee.2017.09.037

El-Sharkawy, M. A. (2004). Cassava biology and physiology. Plant Molecular Biology, 56(4), 481-501. doi: 10.1007/s11103-005-22 70-7

Farias, A. R. N., \& Alves, R. T. (2004). O percevejo de renda na cultura da mandioca. Cruz das Almas, BA: EMBRAPA Mandioca em Foco.

Farias, A. R. N., Mattos, P. L. P., \& Ferreira, J. R. (2007). Artrópodes praga associados à cultura da mandioca em Presidente Tancredo Neves, BA. Revista Raízes e Amidos Tropicais, 3(1), 1-5.

Fialho, J. D. F., Oliveira, M. A. S., Alves, R. T., Pereira, A. V., Junqueira, N. T. V., \& Gomes, A. C. (2001). Danos do percevejo-derenda na produtividade da mandioca no Distrito Federal. (Comunicado Técnico, 48). Planaltina: EMBRAPA Cerrados.

Fialho, J. D. F., Vieira, E. A., Paula-Moraes, S. V., Silva, M. S., \& Junqueira, N. T. V. (2009). Danos causados por percevejo-de-renda na produção de parte aérea e raízes de mandioca. Scientia Agraria, 10(2), 151155. doi: 10.5380/rsa.v10i2.13587
Froeschener, R. C. (1993). The neotropical lace bugs of the genus Vatiga (Heteroptera: Tingidae), pests of cassava: new synonymies and key to species. Proceedings of the Entomological Society of Washington, 95(3), 457-462.

Gisloti, L. J., \& Prado, A. P. (2011). Infestation of cassava genotypes by Neosilba perezi (Romero \& Ruppell) (Diptera: Lonchaeidae). Neotropical Entomology, 4O(5), 613-616. doi: 10.1590/S1519-566X 2011000500014

Gisloti, L. J., \& Prado, A. P. (2013). Aspectos da biologia e morfologia de machos da mosca-dos-brotos (Diptera: Lonchaeidae). Arquivos do Instituto Biológico, 80(4), 416-423. doi: 10.1590/S1808-16572013 000400007

Gisloti, L. J., Uchoa, M. A., \& Prado, A. P. (2017). New records of fruit trees as host for Neosilba species (Diptera, Lonchaeidae) in southeast Brazil. Biota Neotropica, 17(1), e20160213. doi: 10.1590/1676-06 $11-\mathrm{BN}-2016-02$

Graner, E. A. (1942). Tratamento de mandioca pela colchicina: II. formas poliplóides obtidas. Bragantia, 2(2), 23-54. doi: 10.1590/S0006-87051942000200001

Instituto Brasileiro de Geografia e Estatística (2018). Levantamento Sistemático da Produção Agrícola. Recuperado de https:// sidra.ibge.gov.br/tabela/1618

Latif, S., \& Müller, J. (2015). Potential of cassava leaves in human nutrition: a review. Trends in Food Science \& Technology, 44(2), 147158. doi: 10.1016/j.tifs.2015.04.006

Lima, W. H., Ringenberg, R., Fancelli, M., \& Ledo, C. A. D. S. (2018). Resistance of Manihot esculenta and its intraspecific hybrids to the whitefly Aleurothrixus aepim (Hemiptera: Aleyrodidae). Pesquisa Agropecuária Brasileira, 
53(8), 885-891. doi: 10.1590/S0100-20 4X2018000800002

Lorenzi, J. O., Otsubo, A. A., Monteiro, D. A., \& Valle, T. L. (2002). Aspectos fitotécnicos da mandioca em Mato Grosso do Sul. Aspectos do cultivo da mandioca em Mato Grosso do Sul. Dourados: EMBRAPA Agropecuária Oeste/UNIDERP.

Lourenção, A. L., Lorenzi, L. O., \& Ambrosano, G. M. B. (1996). Comportamento de clones mandioca em relação à infestação por Neosilba perezi (Romero \& Ruppell) (Diptera: Lonchaeidae). Scientia Agricola, 53(2/3), 304-308. doi: 10.1590/S010390161996000200019

Lozano, J. C., Bellotti, A. C., \& Vargas, O. (1983). Sanitary problems in the production of cassava planting material. Proceedings of Global Workshop on Root and Tuber Crops Propagation, Regional Workshop Cali, Colombia.

Martinazzo, T., Kraemer, B., Castoldi, G., Fiorese, S., Lohmann, T. R., \& Pietrowski, V. (2007). Flutuação populacional do percevejo de renda na cultura da mandioca na região oeste do Paraná. Anais do Congresso Brasileiro da Mandioca - Paranavaí Resumos Expandidos, Paranavaí, PR, Brasil, vol. 3, 12.

Miranda, A. M., Rheinheimer, A. R., Bellon, P. P., Gazola, D., \& Pietrowski, V. (2009). Biologia do percevejo de renda (Vatiga manihotae) (Hemiptera: Tingidae) em plantas de mandioca. Revista Raízes e Amidos Tropicais, 5(1), 275-279.

Moreira, M. A. B., Farias, A. R., Alves, M. C. S., \& Carvalho, H. W. L. de. (2006). Alternativas para o controle da moscabranca, Aleurothrixus aepim na cultura da mandioca em Sergipe. (Comunicado Técnico, 56). Aracajú: EMBRAPA Tabuleiros Costeiros.
Oliveira, A. M. G., Noronha, A. C., Gomes, H. S., Silva, J., Ferreira, J. R., Fo., Diniz, M. S \& Oliveira, J. L. (2007). Elaboração de sistemas de produção de mandioca para o Extremo Sul da Bahia. In M. G. B. Santos (Ed.), Artigos técnicos divulgados na mídia: coletânea. (Boletim Agropecuário). Brasília: EMBRAPA Recursos Genéticos e Biotecnologia.

Oliveira, F. N. S. (1987). Caracterização botânico-agronômica de cultivares de mandioca (Manihot esculenta Crantz) em Porto Velho, Rondônia. Porto Velho: EMBRAPA-UEPAE.

Oliveira, M. R. V., \& Lima, L. H. C. (2006). Moscasbrancas na cultura da mandioca no Brasil. (Documentos 186). Brasília: EMBRAPA Recursos Genéticos e Biotecnologia.

Oliveira, M. R. V., Moretzshon, M. C., Queiroz, P. R., Lago, W. N. M., \& Lima, L. H. C. (2001). Levantamento de moscas-brancas na cultura da mandioca no Brasil. Brasília: EMBRAPA Recursos Genéticos e Biotecnologia.

Otsubo, A. A., \& Lorenzi, J. O. (2004). Cultivo da mandioca na região Centro-Sul do Brasil. Dourados: EMBRAPA Agropecuária OesteSistema de Produção (INFOTECA-E).

Peña, J. E. \& Waddill, V. (1982). Pests of cassava in South Florida. Florida Entomologist, 65(1), 143-149. doi: 10.2307/3494154

Pietrowski, V., Rheinheimer, A. R., Miranda, A. M., Wengrat, A. P. G. D. S., \& Barilli, D. R. (2014). Ocorrência de Aleurothrixus aepim (Goeldi, 1886) em mandioca na região Oeste do Paraná. Arquivos do Instituto Biológico, 81(2), 186-188. doi: 10.1590/1808-1657000242012

Pietrowski, V., Ringenberger, R., Rheinheimer, A. R., Bellon, P. P., Gazola, D., \& Miranda, A. M. (2010). Insetos-praga da cultura da mandioca na região Centro-Sul do Brasil. 
Marechal Cândido Rondon: EMBRAPA Mandioca e Fruticultura.

Pinto-Zevallos, D. M., Pareja, M., \& Ambrogi, B. G. (2016). Current knowledge and future research perspectives on cassava (Manihot esculenta Crantz) chemical defenses: an agroecological view. Phytochemistry, 130(1), 10-21. doi: 10. 1016/j.phytochem.2016.05.013

Pushpalatha, R., \& Gangadharan, B. (2020). Is cassava (Manihot esculenta Crantz) a climate "Smart" crop? A review in the context of bridging future food demand gap. Tropical Plant Biology, 13(3), 201-211. doi: 10.1007/s12042-020-09255-2

Quaintance, A. L., \& Baker, A. C. (1914). Classification of the Aleyrodidae Part II. Technical Series, United States Department of Agriculture Bureau of Entomology, 27(1), 95-109.

Rheinheimer, A. R., Bellon, P. P., Hachmann, T., Miranda, A. M., Scherer, W. A., Pietrowski, V., Alves, L. F., Pinto, A. S. Jr. (2009). Biologia da mosca-branca (Bemisia tuberculata Bondar) (Hemiptera: Aleyrodidae) em mandioca. Revista Raízes e Amidos Tropicais, 5(1), 265-269.

Rosenthal, D. M., Slattery, R. A., Miller, R. E., Grennan, A. K., Cavagnaro, T. R., Fauquet, C. M., Ort, D. R. (2012). Cassava about FACE: Greater than expected yield stimulation of cassava (Manihot esculenta) by future $\mathrm{CO}_{2}$ levels. Global Change Biology, 18(8), 2661-2675. doi: 10.1111/j.13652486.2012.0272 6. x

Santos, R. S., Coelho, L. B. N., \&Wengrat, A.P.G.S. (2019). Percevejos-de-renda (Hemiptera: Tingidae) associados ao cultivo da mandioca na terra indígena Kaxinawá de Nova Olinda, Acre, com novo registro para o Brasil. EntomoBrasilis, 12(2), 93-96. doi: 10.12741/ebrasilis.v12i2.836
Saunders, J. L., Coto, D. T., \& King, A. B. S. (1998). Plagas invertebradas de cultivos anuales alimentícios en América Central. Turrialba: CATIE.

Schimitt, A. T. (2002). Principais insetos pragas da mandioca e seu controle. In M. P. Cereda (Ed.), Culturas de tuberosas amiláceas Latino-Americano (pp. 351-369). São Paulo: Fundação Cargil.

Silva, A. D. B., Magalhães, B. P., \& Costa, M. $\mathrm{S}$. (1981). Insetos e ácaros nocivos à mandioca na Amazônia. Belém: EMBRAPACPATU.

Souza, J. C., \& Reis, P. R. (1986). Cassava pests in Minas Gerais, Brazil (Pseudococcus sp, Coelosternus rugicollis, Anastrepha sp, Neosilba perezi, Vatiga illudens, Erinnyis ello ello). Belo Horizonte: BINAGRI, Empresa de Pesquisa Agropecuária de Minas Gerais.

Souza, L. S., \& Fialho, J. F. (2003). Sistema de produção de mandioca para a região do Cerrado. Cruz da Almas: EMBRAPA Mandioca e Fruticultura Tropical.

Souza, S. D., Matias, E. C., \& Lopes, E. B. (1982). Cultura da mandioca. João Pessoa: EMATER-PB.

Strikis, P. C., Marsaro, A. L., Jr., Adaime, R., \& Lima, C. R. (2012). First report of infestation of cassava fruit, Manihot esculenta, by Neosilba perezi (Romero \& Ruppell) (Lonchaeidae) in Brazil. Brazilian Journal of Biology, 72(3), 631-632. doi: 10.1590/ S1519-69842012000300029

Vásquez-Ordóñez, A. A., Hazzi, N. A., EscobarPrieto, D., Paz-Jojoa, D., \& Parsa, S. (2015). A geographic distribution database of the Neotropical cassava whitefly complex (Hemiptera, Aleyrodidae) and their associated parasitoids and hyperparasitoids 
Zookeys, 545(1), 75-87. doi: 10.3897/ zookeys.545.6193

Waddill, V. H. (1977). Biology and economic importance of a cassava shoot fly, Neosilba perezi Romero and Ruppel. In T. Brekelbaum, A. Bellotti, \& J. C. Lozano (Eds.), Cassava protection workshop (pp. 209-214). Cali: Colombia.

Weber, P., Barilli, P., Ringenberg, R., Rangel, M. A., Ledo, C. D. S., \& Pietrowski, V. (2015). Incidência de mosca do broto, Neosilba perezi (Romero; Ruppel, 1973) (Diptera: Lonchaeidae) em diferentes genótipos de mandioca. Marechal Cândido Rondon: Embrapa Mandioca e Fruticultura.
Zikan, W. (1944). A mosquinha dos mandiocais, Lonchaea pendula, Bezzi, 1919. Chácaras e Quintais, 70(1), 489-492.

Zucchi, R. A. (2000). Taxonomia. In A. Malavasi, \& R. A. Zucchi (Eds.), Moscas-das-frutas de importância econômica no Brasil: conhecimento básico e aplicado (pp. 3-24). Ribeirão Preto: Holos. 
